\title{
EKSTRAKSI SENYAWA BIOAKTIF SEBAGAI ANTIOKSIDAN ALAMI Spirulina platensis SEGAR DENGAN PELARUT YANG BERBEDA
}

\section{Extraction of Bioactive Compounds as Natural Antioxidants from Fresh Spirulina platensis using Different Solvents}

\author{
Fiya Firdiyani ${ }^{\star}$ Tri Winarni Agustini, Widodo Farid Ma'ruf \\ Program Studi Teknologi Hasil Perikanan Jurusan Perikanan, Fakultas Perikanan dan Ilmu Kelautan, \\ Universitas Diponegoro, Jalan Prof. Soedarto SH, Tembalang, Semarang 50275. \\ Telepon/faks: (024)7474698 \\ *Korespodensi: viyavirdiyani@gmail.com; \\ Diterima 10 Februari 2015/Disetujui 25 April 2015
}

\begin{abstract}
Abstrak
Spirulina platensis adalah mikroalga yang dapat dimanfaatkan sebagai suplemen maupun sumber obat alami yang berpotensi sebagai antioksidan. Antioksidan alami semakin lama semakin diminati oleh masyarakat, karena dinilai lebih aman dibandingkan antioksidan sintetis. Penelitian ini bertujuan untuk menentukan pengaruh pelarut terhadap potensi antioksidan alami Spirulina platensis segar. Metode ekstraksi yang digunakan adalah metode refluks menggunakan pelarut aseton dan etil asetat. Hasil ekstraksi S. platensis segar didapatkan rendemen sebesar 1,86\% untuk aseton, 3,07\% untuk etil asetat. Esktrak Spirulina platensis segar yang diperoleh menggunakan pelarut aseton memiliki nilai $\mathrm{IC}_{50} 65,89 \mathrm{ppm}$ dan dengan etil asetat memiliki $\mathrm{IC}_{50}$ sebesar 76,36 ppm. Kedua ekstrak tergolong memiliki aktivitas antioksidan

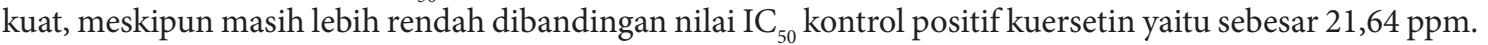
Hasil uji fitokimia (kualitatif) menunjukkan positif adanya senyawa fenolik, triterpenoid, steroid, flavonoid, dan saponin. Nilai $\mathrm{a}_{\mathrm{w}}$ ekstrak pelarut aseton adalah 0,61 sedangkan aw ekstrak pelarut etil asetat 0,81. Hasil penelitian dapat disimpulkan bahwa penggunanaan pelarut yang berbeda menghasilkan aktivitas antioksidan yang berbeda.
\end{abstract}

Kata kunci: Antioksidan, aseton, etil asetat, Spirulina platensis segar

Abstract

Spirulina platensis is a bioactive-rich microalga of great potential as a source of natural antioxidant. Natural antioxidants are increasing in demand, because it is considered as more safe than synthetic antioxidants. The objective of this study was to determine the effect of solvent on the potential of natural antioxidant from fresh $S$. platensis. The antioxidant compound was extracted using either acetone or ethyl acetate by reflux method. The yield of extractions were $1.86 \%$ and $3.07 \%$ for aceton and ethyl acetate, respectively. Fresh $S$. platensis extracts were considered as potential antioxidant source with $\mathrm{IC}_{50}$ values $65.89 \mathrm{ppm}$, and $76.36 \mathrm{ppm}$ when using acetone and ethyl acetate, respectivetly, even though it were still lower compare to the $\mathrm{IC}_{50}$ of positive control quercetin i.e $21.64 \mathrm{ppm}$. Phytochemical test showed positive results of phenolic compound, triterpenoids, steroid, flavanoid, and saponin. $\mathrm{a}_{\mathrm{w}}$ value of Spirulina platensis was 0.61 and 0.81 for aceton and ethyl acetate, respectively. It was concluded that different solvent affected the antioxidant activity of $S$. platensis extract.

Keywords: Antioxidants, aceton, ethyl acetate, fresh Spirulina platensis

\section{PENDAHULUAN}

Spirulina platensis adalah mikroalga yang merupakan sumber hayati yang dapat memproduksi berbagai senyawa kimia yang dapat dimanfaatkan sebagai suplemen maupun sumber obat alami. Utomo dan Adhita (2009) menyatakan bahwa spirulina selain digunakan sebagai pakan alami ikan dan udang, juga diketahui memiliki pengaruh yang baik pada sistem kekebalan. Senyawa kimia yang terkandung dalam S. platensis diantaranya adalah fikosianin yang telah diketahui mampu 
meningkatkan sistem kekebalan tubuh, mengandung antioksidan, antiinfamasi, serta neuroprotective.

Rendemen merupakan suatu nilai penting dalam pembuatan produk. Semakin besar rendemen yang dihasilkan maka semakin efisien perlakuan yang diterapkan dengan tidak mengesampingkan sifat-sifat lain. Rendemen merupakan perbandingan berat kering produk yang dihasilkan dengan berat bahan baku (Yuniarifin et al. 2006).

Senyawa bioaktif merupakan senyawa yang terkandung dalam tubuh hewan maupun tumbuhan. Senyawa ini memiliki berbagai manfaat bagi kehidupan manusia, diantaranya dapat dijadikan sebagai sumber antioksidan, antibakteri, antiinflamasi, dan antikanker. Prabowo et al. (2014) menyatakan bahwa pada berbagai penelitian tentang senyawa bioaktif telah dilakukan untuk tujuan kesehatan manusia, mulai dari dijadikan suplemen sampai obat bagi manusia. Bintang et al. (2007) menyatakan bahwa senyawa bioaktif ini ada yang dapat berfungsi sebagai antibakteri, antikanker, antiinflamasi dan antioksidan. Antioksidan adalah zat yang dapat menunda, memperlambat dan mencegah terjadinya proses oksidasi. Antioksidan sangat bermanfaat bagi kesehatan dan berperan penting untuk mempertahankan mutu produk pangan. Manfaat antioksidan bagi kesehatan dan kecantikan, misalnya untuk mencegah penyakit kanker dan tumor, penyempitan pembuluh darah, penuaan dini, dan lain-lain. Antioksidan dalam produk pangan, dapat digunakan untuk mencegah terjadinya proses oksidasi yang dapat menyebabkan kerusakan, misalnya ketengikan perubahan warna dan aroma, serta kerusakan fisik lainnya (Tamat et al. 2007).

Senyawa antioksidan dapat berupa senyawa alami maupun senyawa sintetik, pada saat ini senyawa antioksidan sintetis sudah mulai ditinggalkan karena memiliki sifat karsinogenik dan antioksidan yang berasal dari alam mulai memegang peranan penting. Senyawa bioaktif yang bersifat antioksidan alam banyak ditemukan di dalam kulit buah pada tumbuhan (Lisdawati dan Broto 2006).
Penggunaan antioksidan sintetis yang dapat membahayakan kesehatan tubuh manusia tersebut mendorong penelitian untuk mencari senyawa alami baru sebagai antioksidan alami yang lebih aman bagi kesehatan manusia. Salah satunya dengan memanfaatkan produk alam dari mikroalga yang diduga mengandung senyawa bioaktif sebagai antioksidan alami. Spirulina yang biasa digunakan pada berbagai penelitian adalah spirulina serbuk sehingga didapatkan permasalahan Spirulina platensis segar berpotensi sebagai sumber antioksidan alami dan perbedaan tingkat kepolaran pelarut dengan menggunakan metode ekstraksi refluks dibantu sonikasi berpengaruh pada aktivitas antioksidannya.

Perbedaan tingkat kepolaran dari pelarut yang digunakan diduga akan menghasilkan ekstrak dengan senyawa bioaktif yang berpotensi sebagai antioksidan alami yang berbeda juga. Sonikasi tersebut bertujuan agar senyawa bioaktif dapat tertarik secara maksimal oleh pelarut. Penelitian ini bertujuan untuk menentukan potensi antioksidan alami Spirulina platensis segar yang diekstraksi dengan pelarut yang berbeda.

\section{BAHAN DAN METODE Bahan dan Alat}

Bahan yang digunakan dalam penelitian ini adalah mikroalga Spirulina platensis yang diambil dari kolam pembudidayaan di CV. Neoalgae, Sukoharjo serta pelarut aseton (Brataco) dan etil asetat (Brataco). Proses ekstraksi dilakukan di Laboratorium Terpadu dan Laboratorium Analisis Program studi Teknologi Hasil Perikanan, Universitas Diponegoro, Semarang. Alat-alat yang digunakan dalam penelitian ini adalah Refluks (Pyrex iwaki), Sonikator (Branson 200), Sentrifuge (Table Top Centrifuge Plc 03 Series), Rotary evaporator (Buchi R 210), Spektrofotometer (Shimadzu).

\section{Prosedur Penelitian}

Proses ekstraksi ini adalah menggunakan metode refluks yang dikombinasi dengan sonikasi. Ekstraksi dilakukan dengan 
mempersiapkan sampel Spirulina platensis segar sebanyak 300 gram dimasukkan ke dalam 2 tabung erlenmeyer masing-masing $150 \mathrm{~g}$, kemudian tabung 1 ditambahkan pelarut aseton dan tabung 2 ditambahkan pelarut etil asetat sebanyak $50 \mathrm{~mL}$. Kedua sampel dimasukkan ke dalam sonikator untuk dilakukan proses sonikasi selama 1 jam dengan gelombang 40 $\mathrm{Khz}$ pada suhu ruang $\left(28^{\circ} \mathrm{C}\right)$. Sampel setelah disonikasi dilanjutkan dengan refluks selama 4 jam pada suhu $50-60^{\circ} \mathrm{C}$. Ekstraksi selesai, sampel disentrifugasi selama 1 jam dengan kecepatan $2500 \mathrm{rpm}$ kemudian disaring dengan kertas saring. Hasil filtrat yang terbentuk dievaporasi dengan rotary evaporator pada suhu $37-38^{\circ} \mathrm{C}$. Hasil ekstrak dimasukkan ke dalam botol vial dan disimpan pada suhu $4^{\circ} \mathrm{C}$. Pengujian yang dilakukan meliputi pengujian fitokimia meliputi alkaloid, senyawa fenolik, triterpenoid dan steroid, flavonoid, dan saponin (Mega dan Swastini 2010), antioksidan dengan metode DPPH (Hatam et al. 2013), dan pengukuran $\mathrm{a}_{\mathrm{w}}$ (Yatno dan Purwanti 2010).

\section{Analisa Data}

Metode yang digunakan pada penelitian ini adalah metode experimental laboratories dengan analisa data secara deskriptif. Metode pengolahan data yang dilakukan adalah dengan cara membandingkan hasil uji dengan kontrol positif, kemudian dijelaskan dengan hasil kulitatif sebagai penguat yang mendukung data kuantitatif.

\section{HASIL DAN PEMBAHASAN}

\section{Hasil Ekstraksi Sampel}

Hasil yang diperoleh dari ekstraksi mikroalga Spirulina platensis dengan berat sampel segar $150 \mathrm{~g}$ disajikan dalam Tabel 1.

Ekstraksi sampel dilakukan dengan menggunakan 2 pelarut yang memiliki tingkat kepolaran berbeda yaitu aseton sebagai pelarut polar dan etil asetat sebagai pelarut semipolar. Setiap tahapan ekstraksi yang dilakukan diharapkan dapat mengekstrak senyawa yang mempunyai kepolaran sesuai dengan kepolaran pelarut. Penggunaan kedua pelarut dipilih karena untuk mendapatkan target senyawa yang tepat sebagai antioksidan, selain itu mampu menarik senyawa berdasarkan tingkat kepolaran dari non polar, semi polar, hingga polar dalam ekstrak yang dikehendaki. Aseton yang bersifat polar akan menarik senyawa yang bersifat polar sampai non polar, begitu juga dengan etil asetat akan menarik senyawa semi polar hingga non polar. Sarastani et al. (2002) menyatakan bahwa pelarut dapat melarutkan ekstrak yang mempunyai sifat kepolaran yang sama. Sari (2011) juga menyatakan bahwa pemilihan berbagai pelarut yang digunakan untuk ekstraksi harus tepat agar dapat menarik senyawa yang dikehendaki.

Proses ekstraksi dengan dua pelarut menghasilkan rendemen yang berbeda untuk setiap pelarut yang digunakan. Rendemen dari pelarut etil asetat lebih besar dibanding dengan rendemen dari pelarut aseton. Hasil rendemen etil asetat adalah sebesar 3,07\% dalam bentuk pasta, sedangkan rendemen aseton adalah sebesar 1,86\% dalam bentuk kering. Rendemen dari etil asetat lebih besar dikarenakan hasil ekstraksi yang diperoleh masih dalam bentuk pasta, hal tersebut disebabkan faktor waktu saat proses evaporasi diduga kurang lama. Waktu evaporasi yang terlalu lama dapat mengakibatkan terjadinya degradasi senyawa bioaktif yang terkandung dalam sampel, sehingga dikawatirkan senyawa bioaktif dalam sampel pelarut etil asetat akan rusak jika terlalu lama. Farida dan Fithri (2014) menyatakan

Tabel 1 Hasil ekstraksi Spirulina platensis segar

\begin{tabular}{lcccc}
\hline Pelarut & $\begin{array}{c}\text { Volum filtrat } \\
(\mathrm{mL})\end{array}$ & $\begin{array}{c}\text { Berat ekstrak } \\
(\mathrm{g})\end{array}$ & $\begin{array}{c}\text { Rendemen } \\
\text { ekstrak }(\%)\end{array}$ & Bentuk \\
\hline Aseton & 142,50 & 2,79 & 1,86 & Kering \\
Etil asetat & 93,50 & 4,60 & 3,07 & Pasta \\
\hline
\end{tabular}


bahwa semakin lama waktu yang digunakan untuk evaporasi dengan rotary evaporator dapat mengakibatkan terjadinya degradasi antosianin, hal inilah yang menyebabkan lebih rendahnya kadar antosianin yang diperoleh.

Pelarut memiliki kemampuan yang berbeda-beda dalam mengambil senyawa bioaktif suatu sampel. Sari (2011) menyatakan bahwa rendemen terbesar diperoleh dari ekstrak polar, sedangkan ekstrak etil asetat menghasilkan ekstrak yang sangat kecil. Senyawa polar memiliki kemampuan mengekstrak senyawa dari kisaran senyawa polar hingga semi polar.

Ekstraksi menggunakan pelarut etilasetat yang merupakan pelarut dengan kepolaran sedang, maka diharapkan yang terekstrak senyawa-senyawa dengan kepolaran yang sedang, begitu pula pelarut aseton diharapkan dapat mengekstrak senyawa-senyawa polar. Kedua pelarut memiliki tingkat kepolaran yang berbeda, sehingga dapat melarutkan senyawa polar, semi polar dan dapat pula melarutkan senyawa yang bersifat non polar. Setyawan dan Yudha (2013) menyatakan bahwa biomassa sel Spirulina platensis akan jauh lebih mudah larut dalam pelarut polar dibandingkan dengan pelarut kurang polar. Pelarut polar dapat melarutkan senyawa polar maupun senyawa non polar karena mempunyai momen dipole yang besar.

\section{Uji Skrining Fitokimia}

Uji skrining fitokimia ekstrak S. platensis segar dilakukan uji kualitatif. Pengujian secara kualitatif hanya untuk mengetahui jenis golongan senyawa bioaktif yang terkandung di dalamnya. Senyawa-senyawa yang memiliki potensi sebagai aktivitas antioksidan yang dapat menangkal radikal bebas. Hasil uji skrining fitokimia secara kualitatif disajikan dalam Tabel 2.

Uji skrining fitokimia ini bertujuan untuk menentukan secara kualitatif ada atau tidaknya golongan senyawa bioaktif yang berpotensi sebagai antioksidan. Golongan senyawa yang diuji antara lain uji alkaloid, uji fenolik, uji triterpenoid, uji steroid, uji fenolik, dan uji saponin. Berdasarkan uji skrining fitokimia dari ekstrak Spirulina platensis pelarut aseton dan pelarut etil asetat menunjukkan hasil positif pada uji senyawa fenolik, triterpenoid, steroid, flavonoid, dan saponin yang hanya terlihat pada pelarut aseton saja. Sudha et al. (2011) hasil uji fitokimia pada S. platensis menunjukkan adanya senyawa terpenoid, saponin, protein, karbohidrat, dan asam amino.

Senyawa alkaloid pada uji skrining fitokimia menunjukkan hasil negatif, yaitu dengan ditandai tidak terbentuk sama sekali endapan berwarna putih maupun coklat, baik pada pelarut aseton maupun etil asetat. Alkaloid merupakan senyawa yang bersifat semi polar namun pada sampel ini tidak terlihat adanya senyawa tersebut. Senyawa alkaloid yang terkandung pada Spirulina platensis segar sangat sedikit bahkan tidak ada. Uji alkaloid akan menunjukkan hasil positif apabila ditandai dengan timbulnya endapan dan perubahan warna menjadi coklat setelah direaksikan dengan pereaksi Mayer. Pereaksi Mayer mengandung logam Hg dan KI yang akan membentuk kompleks endapan kuning kecoklatan dengan senyawa alkaloid. Marliana et al. (2005) hasil positif alkaloid pada uji Dragendorff juga ditandai dengan terbentuknya endapan coklat muda sampai

Tabel 2 Hasil uji skrining fitokimia Spirulina platensis segar pelarut aseton dan etil asetat

\begin{tabular}{lccccc}
\hline \multicolumn{1}{c}{ Sampel } & Alkaloid & Senyawa fenolik & $\begin{array}{c}\text { Triterpenoid } \\
\text { dan steroid }\end{array}$ & Flavonoid & Saponin \\
\hline Aseton & - & ++ & ++ & + & ++ \\
Asil asetat & - & ++ & ++ & ++ & - \\
\hline
\end{tabular}

Keterangan : (-) : Tidak ada dalam ekstrak (+) : Ada dalam ekstrak (++) : Ada kuat dalam ekstrak (Mega dan Swastini 2010) 
kuning. Endapan tersebut adalah kaliumalkaloid. Yudiati et al. (2009) menyatakan bahwa dalam Spirulina sp. memang tidak ditemukan adanya kandungan alkaloid, hal tersebut terlihat pada hasil pengujian skrining fitokimia. Raharjo (2013) menyatakan bahwa alkaloid tidak ditemukan disemua jenis tanaman. Alkaloid kebanyakan ditemukan pada tanaman tingkat tinggi Angiospermae terutama pada tanaman dikotil.

Hasil pengujian skrining fitokimia pada Spirulina platensis segar menunjukkan positif adanya senyawa fenolik, baik pada pelarut aseton maupun etil asetat. Senyawa fenolik tidak hanya dapat larut dalam pelarut aseton saja, akan tetapi juga dapat larut dalam pelarut etil asetat. Hasil uji fenolik menunjukkan hasil positif yang ditandai dengan perubahan warna ekstrak dari bening kehijauan menjadi biru kehitaman. Warna biru kehitaman tersebut dihasilkan dari reaksi antara $\mathrm{Fe}^{3+}$ dengan senyawa fenolik yang terkandung di dalam ekstrak. Fenolik termasuk ke dalam senyawa yang bersifat polar, fenolik dengan muda akan larut dalam senyawa polar yaitu aseton. Ekstrak etil asetat juga menunjukkan hasil positif karena pelarut etil asetat bersifat semi polar yang mempunyai sedikit kemampuan untuk menarik senyawa polar. Pratt dan Hudson (1990) menyatakan bahwa senyawa fenolik terdiri atas molekul-molekul besar dengan beragam struktur, karakteristik utamanya adalah cincin aromatik yang memiliki gugus hidroksil. Fenolik bersifat asam karena sifat gugus $\mathrm{H}^{+}$yang mudah melepaskan diri.

Senyawa triterpenoid dan steroid dari hasil uji skrining fitokimia pada sampel segar juga tampak pada kedua pelarut, baik pada pelarut aseton maupun pelarut etil asetat. Senyawa triterpenoid ini bersifat non polar, akan tetapi pada kedua pelarut menunjukkan hasil positif. Riyanto et al. (2013) menyatakan bahwa senyawa triterpenoid yang dapat dijumpai pada tumbuhan berfungsi sebagai pelindung untuk menolak serangga dan serangan mikroba. Kandungan senyawa triterpenoid pada pelarut etil asetat lebih banyak dibandingkan pelarut metanol.

Hasil uji steroid menunjukkan hasil positif ditandai dengan adanya perubahan menjadi ungu. Steroid merupakan senyawa bioaktif yang tergolong non polar, biasanya senyawa non polar akan tertarik oleh pelarut non polar (like dissolved like), akan tetapi senyawa steroid disini menunjukkan positif pada kedua pelarut yaitu etil asetat dan aseton. Faktor yang mempengarui hal tersebut terjadi adalah adanya momen dipol senyawa polar dan semi polar yang akan menginduksi molekul non polar yang tidak memiliki dipol sehingga akan terjadi gaya elektrostatik di antara keduanya. Gaya ini menyebabkan senyawa non polar dapat larut atau sedikit larut dalam pelarut polar maupun non polar. Steroid memiliki kecenderungan sebagai sumber antibakteri. Bangham dan Horne (2006) menyatakan steroid dapat berinteraksi dengan membran fosfolipid sel yang bersifat impermeabel terhadap senyawa-senyawa lipofilik sehingga menyebabkan integritas membran menurun, morfologi membran sel berubah, dan akhirnya dapat menyebabkan membran sel rapuh dan lisis.

Senyawa saponin bersifat polar menunjukkan hasil positif pada pelarut aseton saja. Saponin memang banyak terkandung di dalam tumbuh-tumbuhan. Shalaby dan Sanaa (2012) menyatakan bahwa hasil skrining fitokimia S. platensis menunjukkan positif adanya saponin hanya pada pelarut polar saja. Saponin termasuk dalam golongan fenolik yang diduga dapat menghambat radikal bebas.

Hasil uji skrining fitokimia menunjukkan positif adanya senyawa flavonoid pada kedua ekstrak Spirulina platensis segar, baik ekstrak pelarut aseton maupun ekstrak pelarut etil asetat. Hasil positif menunjukkan perubahan warna orange kemerahan pada pelarut etil asetat dan orange pada pelarut aseton. Senyawa flavonoid merupakan senyawa yang bersifat non polar, namun flavonoid mempunyai gugus gula yang menyebabkan mudah larut dalam polar ataupun semi polar. Sesuai dengan 
Kar et al. (2006) menyatakan bahwa senyawa flavonoid merupakan senyawa yang bersifat non polar dan banyak ditemukan pada batang tumbuhan.

Metabolit sekunder yang menunjukkan hasil positif pada uji skrining fitokimia diduga mendukung aktivitas antioksidan dari ekstrak Spirulina platensis segar tersebut. Senyawasenyawa tersebut yang dapat memiliki potensi sebagai antioksidan alami yang dapat menangkal radikal bebas. Hirata et al. (2000) menyatakan bahwa senyawa yang memiliki aktivitas antioksidan adalah zeaxanthin, a-tokoferol, dan fikosianin contohnya asam lenoleat.

Hasil nilai IC $_{50}$ yang diperoleh dari penelitian ini didukung oleh hasil uji kuantitatif Agustini et al. (2014) menyatakan bahwa profil senyawa bioaktif yang berpotensi sebagai antioksidan yang terkandung di dalam S. platensis segar diperoleh hasil fenolik total sebesar 3,47 GAE/gr ekstrak untuk pelarut aseton dan etil asetat sebesar 2,04 GAE/gr ekstrak. Nilai fenolik total pelarut aseton lebih besar dibandingkan dengan pelarut etil asetat. Nilai flavonoid total pelarut aseton sebesar $14,25 \mathrm{QE} / \mathrm{gr}$ ekstrak dan pelarut etil asetat sebesar 24,65 QE/gr ekstrak.

\section{Uji Aktivitas Antioksidan dengan Metode DPPH}

Uji aktivitas antioksidan secara kuantitatif dengan metode DPPH dinyatakan dalam nilai $\mathrm{IC}_{50}$ (inhibition concentration). Menurut Andayani et al. (2008), besarnya aktivitas antioksidan ditandai dengan nilai $\mathrm{IC}_{50}$, yaitu konsentrasi larutan sampel yang dibutuhkan untuk menghambat 50\% radikal bebas DPPH.

Berdasarkan pengujian aktivitas antioksidan Spirulina platensis segar dengan metode DPPH dilakukan pada berbagai konsentrasi yang berbeda menunjukkan nilai presentase inhibisi yang berbeda-beda juga. Semakin tinggi konsentrasi ekstrak maka semakin tinggi nilai presentase inhibisinya. Mardawati et al. (2008) menyatakan bahwa semakin tinggi konsentrasi pelarut, maka semakin tinggi persentase inhibisinya, hal ini disebabkan pada sampel yang semakin banyak, maka semakin tinggi kandungan antioksidannya sehingga berdampak juga pada tingkat penghambatan radikal bebas yang dilakukan oleh zat antioksidan tersebut.

Hasil pembacaan absorbansi ekstrak kasar Spirulina platensis segar aseton dan etil asetat dengan dengan berbagai konsentrasi ekstrak dan nilai $\mathrm{IC}_{50}$ menggunakan spektrofotometer pada panjang gelombang $517 \mathrm{~nm}$ diperoleh kurva yang tersaji pada Gambar 1.

Ekstrak kasar Spirulina platensis segar dengan pelarut aseton mempunyai aktivitas antioksidan yang tergolong tinggi atau kuat. Nilai $\mathrm{IC}_{50}$ yang diperoleh adalah $65,89 \mathrm{ppm}$, sedangkan nilai $\mathrm{IC}_{50}$ pelarut etil asetat adalah 76,36 ppm. Ekstrak kasar Spirulina platensis pelarut etil asetat mempunyai aktivitas antioksidan yang lebih lemah dibandingkan dengan ekstrak kasar Spirulina platensis pelarut aseton. Suatu aktivitas dikatakan kuat apabila nilai $\mathrm{IC}_{50}$ nya antara 50-100 ppm. Agustini (2010) menyatakan bahwa pigmen fikobiliptrotein dari Spirulina platensis memiliki $\mathrm{IC}_{50}$ sebesar $96,57 \mu \mathrm{g} / \mathrm{mL}$. Pigmen fikobiliprotein dapat dinyatakan aktif sebagai antioksidan karena mempunyai nilai $\mathrm{IC}_{50}<200 \mu \mathrm{g} / \mathrm{mL}$. Mardawati et al. (2008) menyatakan bahwa suatu senyawa dikatakan sebagai antioksidan sangat kuat jika nilai $\mathrm{IC}_{50}<50 \mathrm{ppm}$, kuat untuk $\mathrm{IC}_{50}$ bernilai 50-100 ppm, sedang jika $\mathrm{IC}_{50}$ bernilai 100-150 ppm, lemah jika $\mathrm{IC}_{50}$ adalah 150-200 ppm, dan sangat lemah jika nilai $\mathrm{IC}_{50}>200 \mathrm{ppm}$.

Aktivitas antioksidan Spirulina platensis segar jauh lebih kuat dibandingkan dengan yang kering atau bubuk. Penelitian Sari (2011) menyatakan bahwa nilai $\mathrm{IC}_{50}$ yang diperoleh ekstrak Spirulina platensis bubuk dengan pelarut etil asetat adalah 11,203 ppm. Aktivitas antioksidan dari ekstrak tersebut tergolong sangat lemah karena nilai $\mathrm{IC}_{50}$ nya lebih dari $200 \mathrm{ppm}$.

Nilai IC $_{50}$ ekstrak dengan pelarut etil asetat jelas menunjukkan lebih besar dibanding 


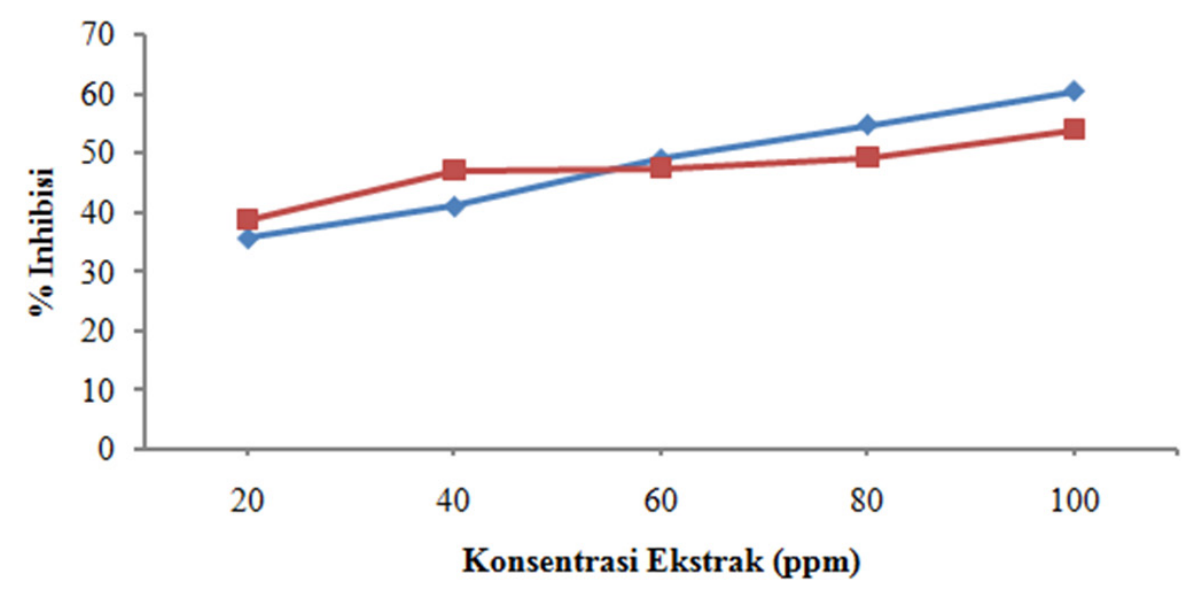

Gambar 1 Kurva aktivitas antioksidan ekstrak Spirulina platensis segar dengan pelarut aseton dan etil asetat berbagai konsentrasi pada panjang gelombang $517 \mathrm{~nm}$ dengan menggunakan spektrofootometer UV-Vis

dengan nilai $\mathrm{IC}_{50}$ dari ekstrak pelarut aseton. Aktivitas antioksidan dari ekstrak Spirulina platensis segar pelarut aseton lebih besar dibandingkan dengan ekstrak Spirulina platensis segar pelarut etil asetat. Menurut Yudiati et al. (2011), semakin kecil nilai $\mathrm{IC}_{50}$ semakin besar aktivitas antioksidannya. Pendapat tersebut diperkuat oleh Sari (2011), yang menyatakan bahwa semakin tinggi nilai $\mathrm{IC}_{50}$ maka aktivitas antioksidannya semakin rendah.

Aktivitas antioksidan pelarut aseton lebih kuat dibandingkan dengan pelarut etil asetat. Aseton yang berperan sebagai pelarut polar mampu menarik senyawa bioaktif yang bersifat non polar hingga polar, sedangkan pelarut etil asetat yang merupakan pelarut semi polar hanya mampu menarik senyawa bioaktif mulai dari yang bersifat non polar sampai semi polar saja. Hasil penelitian menunjukkan bahwa pelarut sangat berpengaruh terhadap aktivitas antioksidan Spirulina platensis segar.

Kedua nilai aktivitas antioksidan dari kedua pelarut tergolong masih rendah apabila dibandingkan dengan nilai aktivitas antioksidan kontrol. Nilai $\mathrm{IC}_{50}$ kontrol adalah 21,64 ppm, nilai $\mathrm{IC}_{50}$ untuk pelarut aseton adalah $65,89 \mathrm{ppm}$ sedangkan untuk pelarut etil asetat adalah $76,36 \mathrm{ppm}$. Semakin kecil nilai $\mathrm{IC}_{50}$ nya maka semakin besar nilai aktivitas antioksidannya. Kontrol positif atau pembanding yang digunakan adalah kuersetin. Aktivitas antioksidan Spirulina platensis yang lebih rendah dibandingkan dengan kontrol diduga karena adanya pengaruh komponen lain dalam ekstrak. Menurut Sari (2011) menyatakan bahwa aktivitas antioksidan yang rendah terjadi karena ekstrak Spirulina platensis yang diekstrak bukan merupakan senyawa murni antioksidan, sehingga diduga masih mengandung senyawa lainnya yang bertindak selain sebagai antioksidan. Hanani et al. (2005) menyatakan bahwa aktivitas antioksidan ekstrak Callyspongia sp. masih lebih rendah.

Aktivitas antioksidan kedua ekstrak Spirulina platensis segar meskipun lebih rendah daripada kontrol, akan tetapi masih tetap tergolong memiliki aktivitas antioksidan yang kuat, karena mempunyai nilai $\mathrm{IC}_{50}$ antara 50-100 ppm. Penelitian ini membuktikan bahwa Spirulina platensis segar memang memiliki kandungan senyawa bioaktif yang berfungsi sebagai antioksidan. Agustini (2010), menyatakan bahwa pigmen fikobiliprotein dari mikroalga Spirulina platensis mempunyai aktivitas antioksidan yang dapat meredam radikal DPPH (1,1-difenil-2 pikrilhidrazil).

Spirulina platensis segar memiliki kandungan senyawa-senyawa bioaktif yang tinggi dan masih bagus, dikarenakan sampel masih dalam keadaan segar dan belum 
mengalami proses pengolahan apapun. Pernyataan tersebut juga merupakan salah satu faktor yang menyebabkan kuatnya aktivitas antioksidan yang dihasilkan. Menurut Hikmah et al. (2009) dalam Sari (2011) hasil pengujian menunjukkan peningkatan lama dan suhu pengeringan pada Spirulina platensis menyebabkan penurunan konsentrasi fikosianin, kadar fenolik total, dan aktivitas antioksidan.

Metode ekstraksi yang digunakan juga diduga sangat berpengaruh terhadap aktivitas antioksidan. Metode ekstraksi refluks dan metode pengujian DPPH diharapkan dapat mengekstraksi senyawa bioaktif secara maksimal sehingga dapat menghasilkan aktivitas antioksidan yang kuat. Shalaby dan Sanaa (2012) metode pengujian aktivitas antioksidan sangat berpengaruh dalam menghasilkan nilai $\mathrm{IC}_{50}$. Perbedaan nilai aktivitas antioskidan ini disebabkan oleh metode ekstraksi, metode pengujian serta kondisi operasi yang digunakan saat proses ekstraksi juga berbeda (volume pelarut, ukuran serbuk daun, waktu ekstraksi, suhu, dan tekanan). Aktivitas antioksidan dipengaruhi oleh metode ekstraksi dan kondisi operasi yang digunakan pada saat ekstraksi.

Kuat atau lemahnya aktivitas antioksidan suatu senyawa dipengaruhi oleh beberapa faktor, diantaranya yaitu komposisi kimia dari Spirulina platensis itu sendiri. Komposisi kimianya juga dipengaruhi oleh kondisi habitat yang meliputi cahaya dan temperatur, tempat Spirulina platensis dibudidayakan. Sari (2011) menyatakan bahwa temperatur dan fase pertumbuhan yang berbeda memberikan pengaruh yang signifikan terhadap kandungan asam lemak dan senyawa biokimia yang dimiliki oleh Spirulina platensis tersebut. Christiana et al. (2008) menyatakan bahwa perbedaan kondisi lingkungan tempat pembiakan spirulina, misalnya $\mathrm{pH}$ media, cahaya matahari serta kandungan oksigen dan nitrogen mempengaruhi perbedaan kandungan bioaktif khususnya klorofil pada spirulina.
Nilai aktivitas antioksidan dari Spirulina platensis memang tergolong tinggi atau kuat, hal tersebut telah didukung oleh hasil screning fitokimia yang menunjukkan adanya senyawa-senyawa yang mempunyai potensi sebagai antioksidan. Senyawa-senyawa yang mempunyai potensi sebagai antioksidan umumnya adalah flavonoid, fenolik, alkaloid, saponin, steroid dan triterpenoid. Menurut Waji dan Andis (2009), senyawa-senyawa yang mempunyai potensi sebagai antioksidan umumnya merupakan senyawa flavonoid, fenolat, dan alkaloid. Menurut Lisdawati dan Broto (2006), senyawa bioaktif yang bersifat antioksidan alam banyak ditemukan di dalam kulit buah atau tumbuhan. Senyawa golongan senyawa metabolit sekunder tumbuhan yang dikenal sebagai sumber radical scavenger adalah golongan senyawa fenol, misalnya flavonol, flavonon, flavon. Fenil propanoid, antakuinon, atau lignan; senyawa-senyawa alkaloid, saponin, dan flavonoid.

Senyawa-senyawa tersebut yang menyebabkan kuatnya aktivitas antioksidan pada Spirulina platensis. Senyawa utama paling kuat yang berperan aktif sebagai antioksidan yaitu senyawa golongan fenol misalnya flavonoid. Waji dan Andis (2009), menyatakan bahwa flavonoid termasuk fenolik alam yang potensial sebagai antioksidan dan mempunyai bioaktivitas sebagai obat. Senyawa-senyawa ini ditemukan pada batang, daun, bunga, dan buah. Flavonoid dalam tubuh manusia berfungsi sebagai antioksidan sehingga sangat kuat untuk pencegahan kanker. Manfaat flavonoid antara lain adalah untuk melindungi struktur sel, meningkatkan efektivitas vitamin C, anti-inflamasi, mencegah keropos tulang dan sebagai antibiotik. Flavonoid dapat berperan langsung sebagai antibiotik dengan mengganggu fungsi dari mikroorganisme misalnya bakteri atau virus. Fungsi flavonoid sebagai anti virus telah banyak dipublikasikan termasuk untuk virus HIV/AIDS dan virus herpes. 
Tabel 3 Hasil uji kadar $\mathrm{a}_{\mathrm{w}}$ sampel

\begin{tabular}{lc}
\multicolumn{2}{c}{ Spirulina platensis segar } \\
\hline \multicolumn{1}{c}{ Pelarut } & Nilai $\mathrm{a}_{\mathrm{w}}$ \\
\hline Aseton & 0,61 \\
Etil asetat & 0,81 \\
\hline
\end{tabular}

\section{Uji $a_{w}$ Sampel Hasil Ekstraksi}

Ekstrak Spirulina platensis segar kemudian diuji kadar $\mathrm{a}_{\mathrm{w}}$ menggunakan $\mathrm{a}_{\mathrm{w}}$ meter. Tujuan pengujian ini adalah untuk mengetahui kadar $\mathrm{a}_{\mathrm{w}}$ dari sampel yang berhubungan dengan kemampuannya sebagai antioksidan. Hasil pengujian kadar $\mathrm{a}_{\mathrm{w}}$ yang didapat disajikan dalam Tabel 3.

Kadar $a_{w}$ juga sangat mempengaruhi oksidasi suatu bahan atau produk. $\mathrm{a}_{\mathrm{w}}$ yang optimal adalah 0,8 atau kurang dari 0,8 , apabila lebih dari 0,8 maka bahan tersebut akan lebih mudah mengalami oksidasi. Hasil pengujian kadar $\mathrm{a}_{\mathrm{w}}$ pada kedua sampel dengan 3 kali ulangan pembacaan menghasilkan nilai ratarata 0,81 untuk sampel dengan pelarut etil asetat dan 0,61 untuk sampel dengan pelarut aseton. Kedua sampel menunjukkan bahwa Spirulina platensis tidak mudah mengalami oksidasi atau dapat dikategorikan mempunyai potensi sebagai antioksidan. Rab (1997) menyatakan bahwa $a_{w}$ dibawah 0,25 menunjukkan bahwa air tersebut terikat dengan erat sekali dalam bahan sehingga tidak dapat berfungsi dalam membantu proses kerusakan. Oksidasi berjalan lambat pada $a_{w} 0,25-0,75$, sedangkan pada $a_{w}$ diatas 0,75 suatu bahan akan dengan cepat mengalami proses oksidasi.

\section{KESIMPULAN}

Ekstrak senyawa bioaktif Sprulina platensis segar berpotensi sebagai antioksidan.

\section{DAFTAR PUSTAKA}

Agustini, N.W.S. 2010. Aktivitas Antioksidan Toksisitas Hayati Pigmen Fikobiliprotein dari Ekstrak Spirulina platensis : Seminar Nasional IX Pendidikan Biologi FKIP UNS. Pusat Penelitian Bioteknologi - LIPI. Bogor.

Agustini, T.W, Widodo F. M, Dhani S. Spirulina :
Teori dan aplikasinya sebagai bahan pangan. Laporan Penelitian MP3EI Tahun Anggaran 2014/2015. Universitas Diponegoro. Semarang.

Andayani R, Maimuna, Y. Lisawati. 2008. Penentuan aktivitas antioksidan, kadar fenolat total dan likopen pada buah tomat (Solanum lycopersicum L). Jurnal Sains dan Teknologi Farmasi 13 (1) :31-37.

Bangham AD, Horne RW.2006. Action of saponins on biological cell membranes. Journal Nature 196: 952-953.

Bintang I.A.K, Sinurat A.P, Purwadaria T. 2007. Penambahan ampas mengkudu sebagai senyawa bioaktif terhadap performans ayam broiler. JITV 12(1) :1-5.

Christina R, Hari K, Leenawaty L. 2008. Photodegradation and antioxidant activity of chlorophyll a from spirulina (Spirulina sp.) powder. Indo Journal Chemistry 8(2):236241.

Hanani, E, A. Mun'im, R. Sekarini. Identifikasi senyawa antioksidan dalam spons Callyspongia sp. dari Kepulauan Seribu. Majalah Ilmu Kefarmasian 2 (3):127-133.

Hatam FS, Suryanto E, Abidjulu J. 2013. Aktivitas antioksidan dari ekstrak kulit nanas (Ananas comosus (L) Merr). Jurnal Ilmiah Farmasi 2(01) : 8-11.

Hirata T, Mikiya T, Masaki O, Teppei T, Morihiko S. 2000. Antioxidant activities of phycocyanobilin prepared from Spirulina platensis. Journal of Applied Phycology 12:435439.

Kar P, Laight D, Shaw K. M, Cummings M. H. 2006. Flavonoid rich grapeseed extracts: a new approach in high cardiovascular risk patients. International Journal Clin Practice 60(11):1484-1492.

Lisdawati V dan Broto. 2006. Aktivitas antioksidan 
dari berbagai fraksi ekstrak daging buah dan kulit biji mahkota dewa (Phaleria macrocarpa). Artikel Media Litbang Kesehatan $16(4)$.

Mardawati, F. Filianty, H. Marta. 2008. Kajian aktivitas antioksidan ekstrak kulit manggis (Garcinia mangostana L) dalam rangka pemanfaatan limbah kulit manggis di Kecamatan Puspahiang Kabupaten Tasikmalaya. Fakultas Teknologi Industri. Universitas Padjadjaran.

Marliana S, Venty S, Suyono. 2005. Skrining fitokimia dan analisis kromatografi lapis tipis komponen kimia buah labu siam (Sechium edule Jacq. Swartz) dalam ekstrak etanol. Jurnal Biofarmasi 3(1):26-31.

Mega M, Swastini D. 2010. Screening fitokimia dan aktivitas antiradikal bebas ekstrak metanol daun gaharu (Gyrinops versteegii). Jurnal Kimia 4 (2):187-192.

Prabowo, A.Y, T. Estiasih, I. Purwatiningrum. 2014. Umbi gembili (Dioscorea esculenta L.) sebagai bahan pangan mengandung senyawa bioaktif: kajian pustaka. Jurnal Pangan dan Agroindustri 2 (3):129-135.

Pratt, D.E, B.J.F. Hudson. 1990. Natural antioxidants not exploited commercially. Else-vier Applied Science. London.

Rab, T. 1997. Teknologi Hasil Perairan. Pekanbaru: Universitas Islam Riau.

Raharjo TJ. 2013. Kimia Hasil Alam. Jogjakarta : Pustaka Pelajar.

Riyanto EI, Widowati I, Sabdono A. 2013. Skrining aktivitas antibakteri pada ekstrak Sargasum polycystum terhadap bakteri Vibrio harveyi dan Micrococcus luteus di Pulau Panjang Jepara. Journal of Marine Research 1(1):115121.

Sarastani D, Soekarto ST, Muhchtadi TR, Fardiaz D, Apriyantono A. 2002. Aktivitas antioksidan ekstrak dan fraksi ekstrak biji antung (Parinarium glaberrimum). Jurnal Teknologi dan Industri Pangan 13(2).

Sari, Rizka F. 2011. Kajian Potensi Senyawa Bioaktif Spirulina platensis sebagai Antioksidan [Skripsi]. Fakultas Perikanan dan Ilmu
Kelautan Universitas Diponegoro. Semarang. Setyawan P.E, Yudha S. 2013. Optimalisasi ekstraksi dan uji stabilitas phycocyanin dari mikroalga Spirulina platensis. Jurnal Teknologi Kimia dan Industri 2(2):61-67.

Sudha SS, Karthic R, Naveen, Rengaramanujam J. 2011. Anti hyperlipidemic activity of Spirulina platensis in triton $\mathrm{x}-100$ induced hyperlipidemic rats. Hygea Journal for Drugs and Medicines 3(2):32-37.

Shalaby E.A, Sanaa M.M.S. 2012. Comparison of DPPH and ABTS assays for determining antioxidant potential of water and methanol extracts of Spirulina platensis. Indian Journal of Geo-Marine Sciences 42(5):556-564.

Tamat, S.R, T. Wikanta, L.S, Maulina. 2007. Aktivitas antioksidan dan toksisitas senyawa bioaktif dari ekstrak rumput laut hijau Ulva reticulata Forsskal. Jurnal Ilmu Kefarmasian Indonesia 5(1):31-36.

Utomo M.T.S, Adhita S.P. 2009. Formulasi pembuatan tablet hisap berbahan dasar mikroalga Spirulina platensis sebagai sumber antioksidan alami. Jurnal Sains MIPA 15(3):167-176

Waji, R.A, A. Sugrani. 2009. Flavonoid (Quercetin). [Skrispsi]. Makasar: Fakultas Matematika dan Ilmu Pengetahuan Alam. Universitas Hasanuddin.

Wikanta, T., H.I. Januar, M. Nursid. Uji aktivitas antioksidan, toksisitas dan sitotoksisitas ekstrak alga merah Rhodymenia palmata. Jurnal Penelitian Perikanan Indonesia 11(4): 41-50.

Yatno, Purwanti. 2010. Pengaruh steaming dan lama penyimpanan terhadap sifat fisik pakan burung perkutut. Jurnal ITP 1(1).

Yudiati E, S. Sedjati, Sunarsih, R. Agustian. 2011. Aktivitas Antioksidan dan Toksisitas Ekstrak Metanol dan Pigmen Kasar Spirulina sp.. Jurnal Ilmu Kelautan 16(4):187-192.

Yuniarifin H, Bintoro VP, Suwarastuti A. 2006. Pengaruh berbagai konsentrasi asam fosfat pada proses perendaman tulang sapi terhadap rendemen, kadar abu dan viskositas gelatin. Journal Indon Trop Anim Agric 31(1) : 55-61. 